\title{
DEVELOPMENT, MANAGEMENT AND ECONOMY OF SHOW CAVES
}

\author{
Arrigo A. CIGNA \\ International Show Caves Association \\ Scientific Advisor to the President \\ Ezio BURRI \\ Dept. of Environmental Sciences \\ University of L'Aquila
}

\begin{abstract}
The problems concerning the development of show caves are here considered by taking into account different aspects of the problem.

A procedure to carry out an Environmental Impact Assessment (EIA) has been established in the last decade and it is now currently applied. Such an assessment starts with a pre-operational phase to obtain sufficient information on the undisturbed status of a cave to be developed into a show cave.

Successively a programme for its development is established with the scope to optimise the intervention on the cave at the condition that its basic environmental parameters are not irreversibly modified. The last phase of the assessment is focussed to assure a feedback through a monitoring network in order to detect any unforeseen difference or anomaly between the project and the effective situation achieved after the cave development.

Some data on some of the most important show caves in the world are reported and a tentative evaluation of the economy in connection with the show caves business is eventually made.
\end{abstract}

\section{Introduction}

Nearly twenty years ago, two great experts of cave management, Russell and Jeanne Gurnee (1981), wrote: "The successful development and operation of a tourist cave depends on a combination of factors, including
1) Scientific investigation
2) Art
3) Technology
4) Management

Scientific study is recommended at the beginning of the first phase in order to determine what hydrologic and geologic factors may have an influence on the develop- 
ment. Art is necessary both in determining the routing of trails and selecting particular cave scenes to feature and in lighting - which is in itself a combination of both art and the next factor, technology. The technology necessary to control water and other natural forces within the cave and to design suitable trails again combines with art to create a tasteful and agreeable cave tour. Management continues from the time the first plans are laid through the developed or operational phase.

The four factors listed above apply both to the development of private caves and public or government lands. Often, because of limited financial resources of a private owner, one or more of these factors is not considered and poor development and lack of financial success may result. Failure of a cave to succeed either through the development phase or after, when the cave is open to the public, can lead to an unprotected area which has been advertised and known to the public and thus subject to vandalism.

In order to ensure that a cave has the highest chance of success as a tourist endeavour, a comprehensive study and evaluation should be made before investment. A cave study provides a "blueprint" which investors, technical people, workmen, exhibitors and administrators can follow to bring about a successful cave operation. The study plan is coodinated by management in order to bring about a procedure which will result in the display of the cave.

With a detailed study and price prospectus at the time the development is originally proposed, a cave can be developed less expensively, more effectively and in less time.

Technological advances in the past fifty years in lighting, communications, transportation, marketing techniques, and almost every phase of cavern development, make it important to find the most efficient ways to complete the project. Every cave must be looked at from the position of the businessman, artist, engineer, speleologist and conservationist. The modification of a natural cave to permit easy visitation of the public requires all of these viewpoints. Balance among these views, through decisions made before beginning the venture, will assure a sound development.

Speleological associations which bring together those caves being considered for tourism will be of great service not only to the group developing a cave, but also in preserving the cave as nearly as possible to its natural state."

It would be really rather difficult to have a better description of the procedure to adopt for the development of a tourist cave.

\section{Preliminary evaluation for the development of a show cave}

In addition to the Environmental Impact Assessment, the procedures devised and 
implemented in the planning phase commonly include those that can quantify certain parameters (topographical, social and economic) used to predict tourist flows. Some of these methodological procedures, well known and successfully applied in the geographic-economic field, tend not to be employed in the development of show caves because of some lack of knowledge.

The topic is included in many models of tourism development, which contain useful references (Miossec, 1976, 1977; Butler, 1980; Hovinen, 1981; Brownlie, 1985; Cooper, 1989). The analyses carried out by Miossec should be particularly underlined, since they tend to determine the structural evolution of tourism zones in space and time. In this context, four basic elements are taken into account:
1) Tourism localities;
2) Transport network;
3) Behaviour of tourists;
4) Attitudes of local authorities and the general population.

Indeed, expansion of the tourism industry inevitably involves development of the tourism localities and transport network, understood both as roadways and public transport systems. This industry tends to become more and more complex and diversified in terms of what is offered. Therefore, tourists become increasingly aware of the possibilities that the site, and its surrounding area, can offer, and consequently their behaviour changes. The change in local attitudes can ensure that tourism is totally accepted, thus leading to the adoption of short- and long-term planning schemes; however, it can also lead to the rejection of tourism, and such cases have been reported in the literature. It is evident that the evolution of tourism spaces (and in this case the scale can range from a microregion to a large geographical area) follows a series of stages, outlined in Fig. 1. It is necessary to specify that the territorial size of a microregion is similar to that of a single show cave and its surrounding area; indeed this analysis deals exactly with this particular case:

Phase 1) The recently discovered cave is visited by a few connoisseurs who generally accept (and in some cases appreciate) the total lack of logistic support. The territory is crossed but not visited, and the general attitude of the local population and political-administrative authorities is rather uncertain. Often the initiative and, accordingly, the possibility or desire for investment is lacking.

Phase 2)The cave is fitted out by means of provisional interventions, with rather elementary management criteria. The local populations look on with doubtful curiosity 
or indifference, this attitude being explained by mistrust of the central authorities; the first tourists have only a very general perception of the surrounding territory. Often the importance of the cave is overestimated with respect to expectations, which almost always refer to enduring conditions of high interest, and this causes a loss of interest by both the tourist and the few people involved in management, with consequent abandonment of the completed infrastructure.

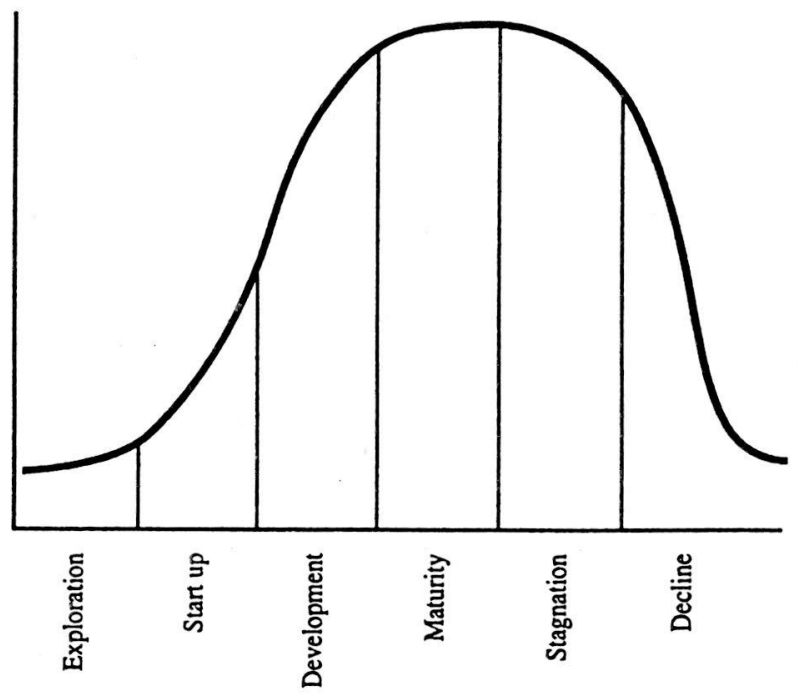

Fig. 1 - Life cycle of a tourism area (from Cavallaro \& Pipino, 1991; modified)

Exploration: a small group of adventurous tourists that reject institutionalised vacations. The areas are rather intact environmentally. Low impact on the local lifestyle.

Start-up: initial formation of a tourism area, with local people who organise the project. There is pressure on the public sector for funding.

Development: considerable tourist flows, outnumbering the residents in the busiest period. Local initiatives cannot control the tourism. The quality decreases on account of intense use of the structures and overcrowding.

Maturity: there is growth with decreasing marginal trends. The site is famous, but the tourist pressure separates it from the surrounding environment.

Stagnation: the maximum number of tourists is achieved, with environmental, social and economic problems.

Decline: the number of tourists decreases and the destination has an ever-smaller area of origin of tourists. New structures may be introduced to revitalise the locality.

Phase 3) The early initiatives have shown that interest in the show cave can progress and develop, with multiplication of the infrastructure. Other resources are involved 
(e.g. food products and local handicrafts), with greater employment of manpower, essentially the seasonal type. The number of tourists increases and their perception of the area improves. The local populations actively participate in the realisation and management of reception and support structures.

Phase 4) In response to the increasing demand, a preliminary organisation of the territory is carried out. Forms of specialisation and competition in management of the tourist space appear. The local population perceives the difference between its economic and social condition and that of the tourists and assumes imitative behaviours. Feelings of cultural expropriation and the first forms of environmental degradation inside the cave, and in the surrounding territory, begin to appear.

Phase 5) The show cave is only the primary attraction and other poles of extremely diversified interest and often (since they are artificial) with weak intercultural connections are developed. The group of attractions is structured as a hierarchical pyramid system. The structures and transport system are extremely efficient, with an increasingly massive tourist flow, to the point where the type of urban space that was once avoided is now recreated and the tourist perceives the environment as a "false" attraction founded on fictitious natural models based on advertising messages. The cave is reaching high levels of saturation and has been subjected to notable restructuring and expansion of the route, with increased tourist flow and consequent serious, even irreversible, degradation. This is the most critical phase which if it becomes chronic leads to the most serious damage, especially from the environmental point of view.

There are many possible solutions that can be proposed in this sector, mainly concerning non-traumatic revitalisation of tourist circuits with saturation of interest (Burri \& Cigna, 1991).

As mentioned, the models dealt with here have been devised and tested in situations different from those of a show cave and thus their application may involve problems of adaptability. However, if this happens it is certainly not because of lack of inherent suitability of the model - indeed, these procedures are fairly well known and applied in specific sectors (e.g. the classical seaside or mountain tourism sites) where they have generated productive discussions - as much as the absolute lack of specific case studies like those of show caves. This is due to a series of not easily resolved problems, including, paradoxically, the unavailability of data concerning the true magnitude of visitor flows, especially for show caves of local interest.

In this regard, however, it is necessary to consider a fundamental concept, i.e. the vis- 
itor capacity as a limiting factor. In the next paragraph the procedures to determine this parameter, which remains propaedeutic for any other planning initiative are described. If the values of this parameter predict a rather low limit for frequentation, any intervention would be useless since the costs of installation and management can never be recuperated or amortised, nor can management produce profits. However, in the history of tourist exploitation of some Italian caves (especially in the recent past, when the use of these procedures was already known), almost all the basic structures (tour pathways, lighting systems, services) have been established independently of their prospects for economic profit and with the financial intervention of the central government.

This type of initiative, common in other European and non-European countries, is similar to the incentives provided for enterprises using private or mixed (public/private) capital. In fact, public intervention is normally limited to substantial funding (up to $100 \%$ ) for the realisation of basic and infrastructural works; the management is left to local enterprises, often with the creation of "management consortiums" with mixed capital that also involves local administrations (Municipalities, Provinces, Mountain Communities, etc.). It is clear that the limiting factor, the visitor capacity, which has not been considered in calculation of the amortisation of non-repayable financing, will nevertheless have to be considered in relation to the estimated costs of management and maintenance of installations subject to natural wear and tear.

Caves, which have a very low receptive capacity, are areas with high environmental risk and thus not very suitable for mass tourism. The only possible alternative in this case is to equip the caves with routes that can be fairly easily realised and maintained - for example, excursion-type guided visits, with internal routes lacking illumination and with a low environmental and economic "burden" (Burri \& Forti, 1995). Possible funding aimed at revitalising the local economy can be diverted to other sectors of environmental interest worthy of development and with less risk of degradation.

\section{The visitors' capacity of a tourist cave}

The concept of an environmental capacity has been accepted for years. It has been used for the management of low-level radioactive wastes (Amavis et al., 1974) and in range management in the United States (called carrying capacity) (Huppert et al., 1993).

Aley (1976), Brucker (1976), Van Cleave (1976), Forssell (1977), and Middaugh (1977) have extensively discussed the concept of 'visitors carrying capacity' as applied to caves in the literature. Van Cleave (1976) showed that there must be a commitment to cave and karst protection in both desire and money in order for the concept to work. Middaugh (1977) cautioned that carrying capacity is not the calcu- 
lation of a number but rather, it is the definition of a problem, the definition of objectives to solve that problem, and the implementation of proper management to solve the problem. At this time, most of the well-known tourist caves in the world were undoubtedly operated at levels well above any reasonable or environmentally derived carrying capacity.

Cigna $(1989,1990)$ expanded on this concept with respect to caves as follows: "Visitors capacity can be defined as the maximum number of visitors acceptable in a time unit under defined conditions which does not imply a permanent modification of a relevant parameter." This definition is based on the following assumptions:

1. Natural fluctuations of environmental parameters are considered safe for the integrity of the environment itself. This concept implies that abnormal (and unusual) phenomena are excluded. For example, a volcanic eruption may be the cause of a natural fluctuation, which could destroy a cave. Therefore the range of natural fluctuations must be limited within the extreme values that do not result in irreversible effects on a short-term basis.

2. If the number of visitors in a cave per unit time is gradually increased, one environmental parameter will exceed the range of its natural fluctuation prior to other parameters. Such a parameter can be defined as a critical factor. The term 'critical' need not imply any idea of danger. It describes a factor, which enables managers to make decisions on levels of protection for the cave environment.

3. The visitor capacity corresponds to the maximum flow of tourists through the cave that changes the critical factor to the limit of its natural fluctuations.

4. The classification of environmental parameters into major and minor parameters is rather arbitrary. If air temperature, carbon dioxide concentration, and water quality are classified as major parameters, the appropriate classification of the other parameters may require detailed study. The significance of the other parameters may vary widely among caves.

The establishment of the maximum number of visitors is difficult and may well be impossible in some cases. Sometimes these numbers have been used to satisfy management objectives by those who, unfortunately, may put a higher priority on moving people (and therefore increasing revenue) than on protecting the karst.

Aley (1976) described another important problem in caves, which can actually become exacerbated by the use of carrying capacity numbers as a management technique. He correctly argued that most show caves have abundant non-renewable resources in their speleothems display. Once damaged, these resources cannot be replaced, at least not in human lifetimes. A cave with one or more highly decorated 
passages could require a low carrying capacity if the decorations are within human reach of the trail, or within the sphere of influence of human-induced changes that adversely affect the speleothems. As damage is incurred and speleothems are removed, broken, defaced, or tainted, then the passage becomes less pristine. At that point, it can be argued that the carrying capacity has risen because fewer speleothems now remain to be damaged and the quality of the experience has been denegated. This is contrary to the entire concept of carrying capacity, which dictates that use levels should decline as the resource declines. This is a phenomenon often ignored by cave managers. However, if the goal is to maintain any specific show cave in a pristine or near-pristine condition, a realistic number of visitors must be determined and applied as a management criterion. To do this with any level of confidence, a thorough study of each cave's features, ecosystem parameters, and hydrology must be made. This is undoubtedly a difficult task, given the budget constraints of some show caves, whether managed by some level of government or by the private sector. In the long run, however, this may be the most cost-effective alternative, in order to sustain the tourist-derived revenue from the cave, concomitant with sustaining its ecological and aesthetic integrity.

The concept of carrying capacity was also questioned, as it is applied to general recreational use. Hammitt and Cole (1987) felt that strict use of the concept in the recreational setting does not work well for two reasons. First, the impacts of recreational uses differ greatly from those of range animals (for which, according to the authors, the concept was originally designed to control). Second, they argued that the concept ignores the impact on the visitor's aesthetic experience; i.e., the social carrying capacity (defined as how people feel about the quality of the experience) must also be measured. However, this can vary greatly among individuals. While it may be possible to subdivide surface reserves to accommodate the tastes of the various users (e.g., from high impact use such as off-road vehicle areas to near-pristine wilderness), similar possibilities are quite limited in show caves. Unfortunately, the authors know of no study that applies this concept to the cave environment in a quantitative method.

Some years ago, Heaton (1986) reviewed the concept of energy levels as applied to caves. He classified caves into one of three categories: high-energy, moderate-energy, and low-energy levels. High-energy caves experience high-energy events on a regular basis. An example would be those caves that undergo periodic flooding. The strongest forces normally encountered by moderate-energy caves are orders of magnitude lower than those associated with high-energy caves. The most significant forces may be running water, persistent wind, or even the activities of animals. Lowenergy caves are again orders of magnitude smaller. Often in these caves the highest energy event may be a falling drop of water.

According to this classification, high-energy passages will be minimally affected by tourist activities because such passages will be rearranged by rockfall or flooding 
within a year. In moderate-energy passages, which often have the most abundant displays of speleothems, the presence of visitors may have a more lasting effect. During short periods of time the energy released by tourists can be of the same order of magnitude as that released by natural processes which normally operate in those caves. This could lead to irreversible damage.

A visit to a low-energy cave may have more serious implications because in a very short time interval more energy could be released than it had experienced in perhaps a thousand years. The damage caused by one group of visitors may be profound and the speleothems may quickly be destroyed. It is the authors' experience that most tour caves are found to be in the low to moderate energy range, due to the difficulty and great cost of developing and maintaining high energy tour caves.

The field situation is far-more complex than the simplified examples of energy levels given above. A single cave may exhibit examples of all three energy levels when different sections of a given cave are considered. Because, in principle, tourist trails may cross all three energy levels, each area should be regarded separately in a coherent overall management plan. Devising and implementing such a plan would undoubtedly be a complicated and expensive process.

The use of a visitor carrying capacity model could be modified to 'fit' certain caves that have unique resources. For example, those caves with rare and generally irreplaceable cultural, biological, and/or speleothem resources and which are easily destroyed merely by the presence of visitors should be managed in a very restrictive manner. Caves in this category would be few and considered national or international treasures. Two examples are Lechuguilla Cave in the U.S.A. and Lascaux in France.

Another category could be those caves with rare and significant ecological resources that could be sustained even with visitation, providing they have adequate management. An example would be the glow-worm resource in Waitomo Glow-worm Cave in New Zealand. The last category would be those caves with minimal cultural, ecological or speleothem resources. This type of classification is already being carried out in many of the undeveloped caves on federal government managed land in the United States.

In many cases, caves with significant resources require permits to enter and limits are put on party size; also, visitation may be restricted to a particular time of year and there may be limits as to where one can travel in the cave. These management techniques help control and direct traffic to minimise damage. They also restrict most damage to heavily travelled routes and create a distance-decay relationship of impacts as distance from the trail increases. This relationship generally applies to large show caves where the tourist route is only a small fraction of the entire cave. Applying the concept of visitor carrying capacity to a tourist cave to set a maximum number of visitors is a difficult, however compelling, exercise. It should be undertaken after fully assessing all of the environmental data collected. In some cases, the 
most difficult task will be to have the political courage to resist pressure to allow excessive visitation for the sake of efficiency or tourist revenue.

\section{The sources of disturbance to the cave environment}

The different sources of disturbance, which may modify the natural equilibrium of the cave environment, are here considered and their quantitative influence evaluated (Cigna \& Forti, 1989; 1990; Cigna et al., 2000).

\section{The effects of lighting.}

The lighting system in a cave will contribute a certain amount of heat. If it is not compatible with the global energy budget of the cave, the inside temperature will increase and reach stationary values higher than the natural ones. Of course it is necessary to consider separately the contribution of each possible source (lighting, visitors, other heat sources) in order to consider it in the frame of the cave capacity to accept such contribution without not-reversible consequences.

In the vicinity of the light sources the effects may be both physical (thermal) and biological. When lamps are not "hight efficiency" lamps, the thermal effect can be very important. E.g. in Castellana Caves, South Italy, the temperature of a rock wall at 50 $\mathrm{cm}$ from a $1 \mathrm{~kW}$ lamp increased in a few seconds from $15^{\circ} \mathrm{C}$ to more than $25^{\circ} \mathrm{C}$ while the relative humidity decreased from $95-100 \%$ to $55-60 \%$ and a strong upward air current was established. As a consequence of these effects (which are rather peculiar) aragonite flower grew on a calcite stalagmite (Forti, 1980).

In the biological domain a rather widespread effect is the proliferation of algae and mosses near the light sources. These organisms not only have an aesthetic negative influence on the cave environment but can also set up a corrosion of speleothems by biochemical processes. Incandescent lamps are still widely used and have an emission spectrum rather large covering many absorption bands typical of vegetal organisms (Imprescia, 1983).

\section{The effects of tourists.}

The presence of visitors in a cave may imply different types of pollution: thermal, chemical and biological. The calculation of the thermal pollution is not very easy because the heat released by a person varies within a wide range as a consequence of some environmental factors (air temperature, relative humidity) and some sourcerelated factors (size, velocity, dress, etc.).

Some field measurements carried on by Villar et al. (1984) in the Hall of Paintings in the Altamira Cave (Spain) evaluated a heat release per person ranging between 82 and 116 Watts $(1 \mathrm{~W}=1 \mathrm{~J} / \mathrm{sec}$ ). If a person is walking, the heat release can be assumed to be about $170 \mathrm{~W}$ and, therefore, the annual heat input, $\mathrm{E}$ (in $\mathrm{J} / \mathrm{sec}$ ) will be given by:

$$
\mathrm{E}=170 \cdot \mathrm{t} \cdot 3600 \cdot \mathrm{N}
$$


where:

$\mathrm{t}$ is the average visit time in hours

$\mathrm{N}$ is the total number of visitors in one year

To have an idea of the amount of heat released in an actual case, such a calculation can be made for an important show cave. Assuming 500,000 visitors per year and an average visit length of 1.5 hours, the total amount of heat released by visitors is $4.59 \cdot 10^{11} \mathrm{~J} / \mathrm{sec}(=128 \mathrm{MWh}$ ) each year. Therefore the effects in a moderate-energy cave can be very large.
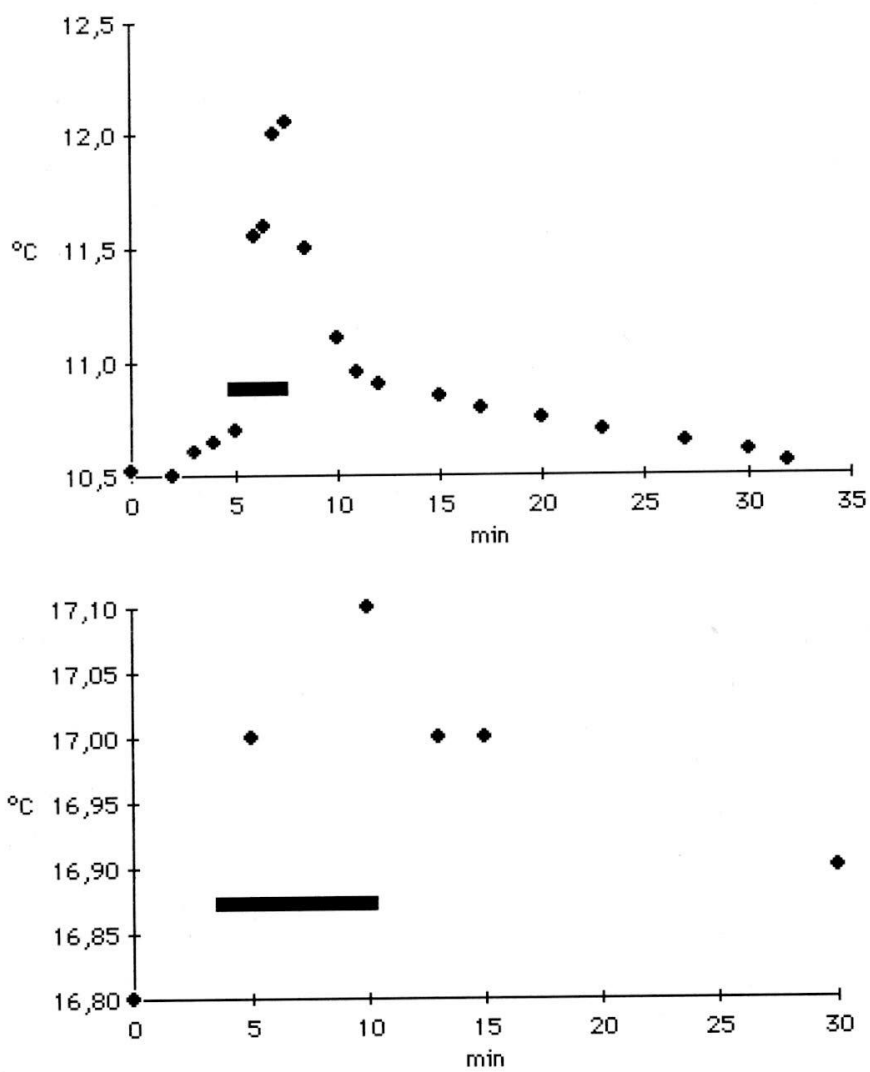

Fig. 2 - Upper diagram: air temperature measured in the cave of Remouchamps (Belgium) after the transit (near the "Boudoir des Fées") of a group of 87 tourists (black line) (from: Merenne-Schoumaker, 1975). Lower diagram: air temperature measured in the cave of Castellana (Italy) after the transit (in the "Corridoio del deserto") of a group of 105 tourists (black line) (from: Cigna, 1989).

The heat emitted by visitors raises the air temperature: in Fig. 2 two examples of this effect are reported.

The recovery time after the tourists transit is some ten minutes long. 
In the case of the Castellana Cave (Bari, Italy) the global heat input from visitors and from the lighting system modified the thermal equilibrium of the cave. In an interval of 22 years an increase of about $3^{\circ} \mathrm{C}$ of the indoor air temperature (Fig. 3) was measured (Mongelli, 1961; Forti \& Cigna, 1983; Cigna, 1989).

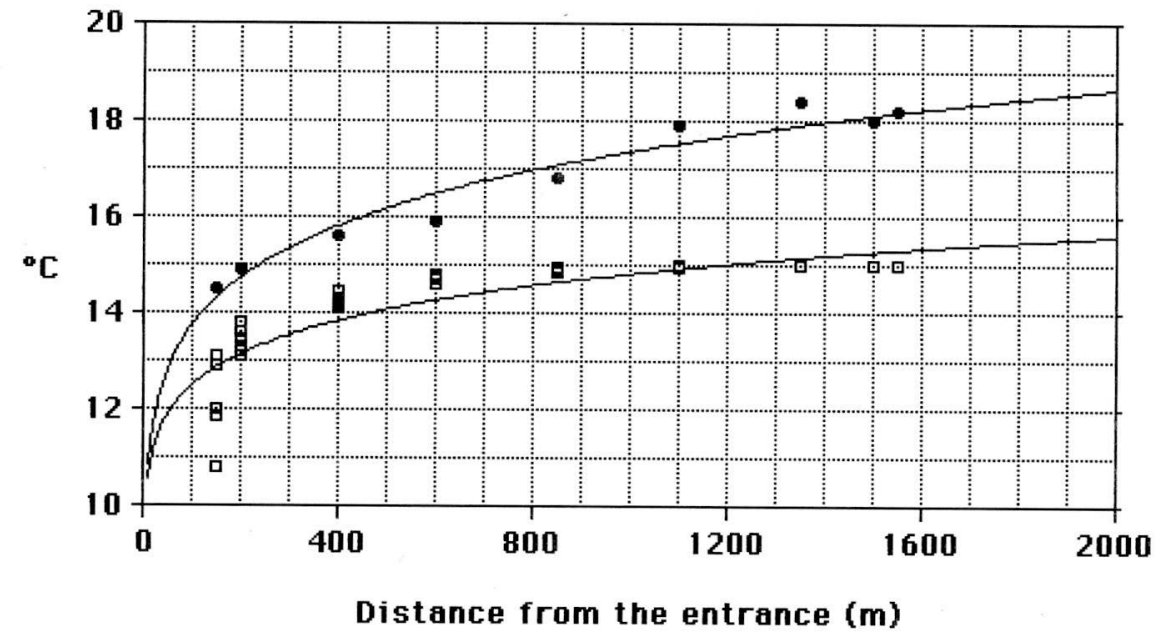

Fig. 3 - Distribution of air temperatures in the Castellana Cave (Bari, Italy). Measurements made in 1958-60 (squares; Mongelli, 1961) and in 1982 (dots; Forti \& Cigna, 1983) are reported; an average increase of about $3^{\circ} \mathrm{C}$ is quite evident.

The chemical pollution originated by visitors is mainly due to the emission of carbon dioxide; any increase of the carbon dioxide concentration may affect, in principle, the chemical equilibria of the cave formations. Such effects are, of course, much more important in low and moderate-energy caves. Villar et al. (1985) reported seasonal variations of some chemical parameters (bicarbonates concentrations, dry residue and $\mathrm{pH}$ ) of percolating waters in Altamira Cave; however no permanent changes were observed over a long period.

A model predicting the carbon dioxide variation in function of visitor-flow was described by Villar et al. (1986). The carbon dioxide concentration is proportional to the number of visitors and the time of their stay (for intervals $<1$ hour) according to the relation:

$$
\Delta \mathrm{C}(\mathrm{t})=\frac{17 \cdot 10^{3} \cdot \mathrm{N} \cdot \mathrm{t}}{\mathrm{V}}
$$

where: $\quad \Delta \mathrm{C}(\mathrm{t})$ is the variation of the carbon dioxide concentration (ppm, vol) at time $\mathrm{t}$

$\mathrm{N}$ is the number of visitors

$\mathrm{t}$ is the time of stay of visitors (hours)

$\mathrm{V}$ is the volume of the cave hall $\left(\mathrm{m}^{3}\right)$ 
In Altamira Cave the carbon dioxide concentration recovered to the original level after 12 hours if groups of 6 persons were in the cave with a time of permanence from 20 minutes to 1 hour (i.e. $\Delta \mathrm{C}(\mathrm{t}=12)=0$ ). In other cases, as for the "Grotta Bianca" in Castellana Cave, the recovery time is much longer with negative effects both on comfort of visitors and, perhaps, the cave formations.

With reference to carbon dioxide is must be emphasised, nevertheless, that, in addition to a contribution from the visitors, a source due to some natural process has already been envisaged (Castellani, 1988; Caumartin, 1993). Recent studies carried out by the team of the Laboratoire Souterrain de Moulis (France) in a famous show cave, the Aven d'Orgnac identified such a process. They found that the variation of $\mathrm{CO}_{2}$ concentration was inversely proportional to the variation of oxygen concentration. The isotopic analysis of carbon of $\mathrm{CO}_{2}$ pointed out a biogenetic origin and the ratio between the isotopes of helium were typical of the atmosphere and not of a deep origin gas (Bourges et al., 1998).

Therefore it was concluded that about $2000 \mathrm{~kg}$ of $\mathrm{CO}_{2}$ were produced each day by natural processes in that cave at the end of the Summer, against about $170 \mathrm{~kg}$ released by tourists in the same time interval. It is evident that in that case the role of visitors as source of $\mathrm{CO}_{2}$ is less than $10 \%$ with respect to natural processes.

Such a situation is not peculiar to Aven d'Orgnac because in many other caves relevant variations of $\mathrm{CO}_{2}$ concentration were detected and their connection with the tourists was sometimes difficult to explain.

The biological pollution contributed by the visitors is due to their "cloud" of spores and bacteria. The consequence of the biological pollution seems to be not only the growth of mosses and plants around lamps. According to an hypothesis recently advanced by Cser \& Gadoros (1988) some eccentrics could be originated by aerosols; the increase of condensation nuclei due to spores and droplets in the breath of visitors could reduce the concentration of aerosols responsible for the eccentrics growth with an enhanced transformation of eccentrics into coralloid formations, as it was observed in some commercial caves.

Finally, another form of pollution is introduced by tourists as lint (Michie, 1996). Such a dust is composed of hairs, dry-flaking skin, and dust from shoes and lint from clothing. In Carlsbad Cavern, USA, the average yearly rate of long-term lint accumulation in the cave was estimated at $2 \mathrm{~kg} /$ year (Jablonsky, 1990). In Ngilgi Cave, Western Australia, a deposition rate of $8.3 \cdot 10^{-3} \mu \mathrm{g} \mathrm{m}^{-2} \mathrm{~d}^{-1}$ was measured (Michie, 1997). It is evident that this kind of pollution may result in a threat to show caves. According to Michie (1997) if the use of the cave will cause dust deposition that exceeds a threshold of $0.7 \%$ in a chosen time period then it should be considered to protect the cave by constructing pathways that enable management of the dust problem.

Some protective measures against pollution effects.

As it was outlined above, in some caves, particularly in those with moderate-energy 
levels, the influence of visitors can play an important role in the global energy balance of the cave. Nevertheless there are some simple measures which could help to reduce undesirable effects.

The use of "hight efficiency" lamps and, in any case, the positioning of lamps at some distance from the cave walls would reduce the thermal pollution or, at least, some local consequences (Caumartin, 1993). To keep the amount of input energy as low as possible, the lighting system could be divided into many sections in order to have as few lamps as possible lit up at the same time.

Concerning the visitors, their time of stay in the cave must be limited; such a result can be achieved both by limiting their number and by a shortening of the visitors trail (e.g. by opening an artificial entrance which, in principle, could halve the time of a visit by the elimination of the return walk within the cave).

It must be emphasised that the opening of artificial entrances may result in important changes of the cave microclimate by inducing airflows, which modify the natural air circulation. Therefore it is imperative to provide an air lock in the artificial tunnel. Such air locks are normally obtained by installing sliding doors operated automatically by a photocell. This solution is expensive because it requires at least two or three doors to avoid any airflow and may cause claustrophobia to some persons.

R. Gurnee (1990) suggested an elegant solution to the problem by the use of air-curtains, which are usually mounted over entranceways of warehouses. An air-curtain uses a "wall" of air recirculated by fans in a cross section of a passage. This system has many advantages because it is completely invisible and non-obstructing to tourists, it seals itself around people passing through it and reduces the infiltration of dust and spores carried along by visitors.

A couple of air-curtains installed one after the other and operated alternatively every other day assure their operating capacity so that, in case of a failure, one air-curtain is surely available until the other one is fixed. In addition the risk of a failure is reduced with respect to a mechanical door because the only part in movement is the fan which is a rather robust and reliable apparatus.

This limitation of the time of visitation will provide not only a reduction of the input of heat to the cave but also a reduction of the chemical pollution. In some special cases, when the increase of $\mathrm{CO}_{2}$ concentration is threatening speleothems and a limited cave environment is concerned (less than some hundreds of $\mathrm{m}^{3}$ ), a simple system consisting of a fan filtering the air through an absorber (e.g. $\mathrm{NaOH}$ ) could be very successful.

Such a system could be fully automatic, being switched on by a sensor when the concentration of carbon dioxide in the atmosphere is higher than a predetermined level. The absorber must be changed when exhausted and the wastes must be removed from the cave to avoid any further pollution.

The growth of algae and mosses in proximity to light sources can be greatly reduced or entirely avoided by the use of special vapour discharge lamps which have a light 
emission limited to some narrow bands not useful for the physiological processes of plants (Imprescia, 1983).

\section{The Environmental Impact Assessment (EIA) for caves.}

In early 1970s the process of impact statements on the surface was proposed by $\mathbf{J}$. Gurnee (2001) to be extended also to the underground. Land Use Planning for show caves was therefore proposed when cave owners had not yet considered the creation of a master plan for their land. As a result of their not preparing a master plan, a number of caves had made large parking facilities for visitors that prevented the percolation of waters into the cave, preventing the process of speleothem formation and growth below.

Now it is commonly known that the surface and underground are inexorably linked and cave development must be planned with this in mind.

To ensure the best application of the criteria reported in the previous section and to control the feedback to the cave environment from a tourist development, a procedure to establish an Environment Impact Assessment (EIA) has been developed. In fig. 4 the steps for such an assessment of a tourist cave are summarised.

If possible data collection of the main parameters of the cave climate should be collected during one year (at least) before the start of any intervention on the cave. Such a collection can be obtained either by spot measurements or by data loggers which are presently rather inexpensive and assure a continuous monitoring without attendance of personnel. In fact data can be discharged every few months, according to the frequency of measurement.

Once an energy balance of the cave is obtained, the perturbation due to the cave development (lighting, pathways, etc.) and visitors can be evaluated and compared to the natural variation of the parameters taken into consideration. An optimisation of the project is then set up on the basis of the constraints given by the protection of the cave environment and the requirements of the commercial exploitation.

It is convenient to establish an ad hoc scientific committee in the early phase of the cave development in order to insure the best implementation of the results of the monitoring of the project. In addition such a scientific committee will play an important role after the cave is open to tourists. In particular monitoring would compare the visitors' capacity as evaluated by the previous monitoring with the real effects of the visitors to avoid that the uncertainty of the determination of some environmental parameters would not lead to unacceptable consequences.

In some instances this scientific committee has played an additional role, in co-ordinating scientific researches in the cave. This was the case of the Caves of Frasassi (Ancona, Italy) where the committee promoted a large number of studies, that were successively published (Bertolani \& Cigna, 1994). 


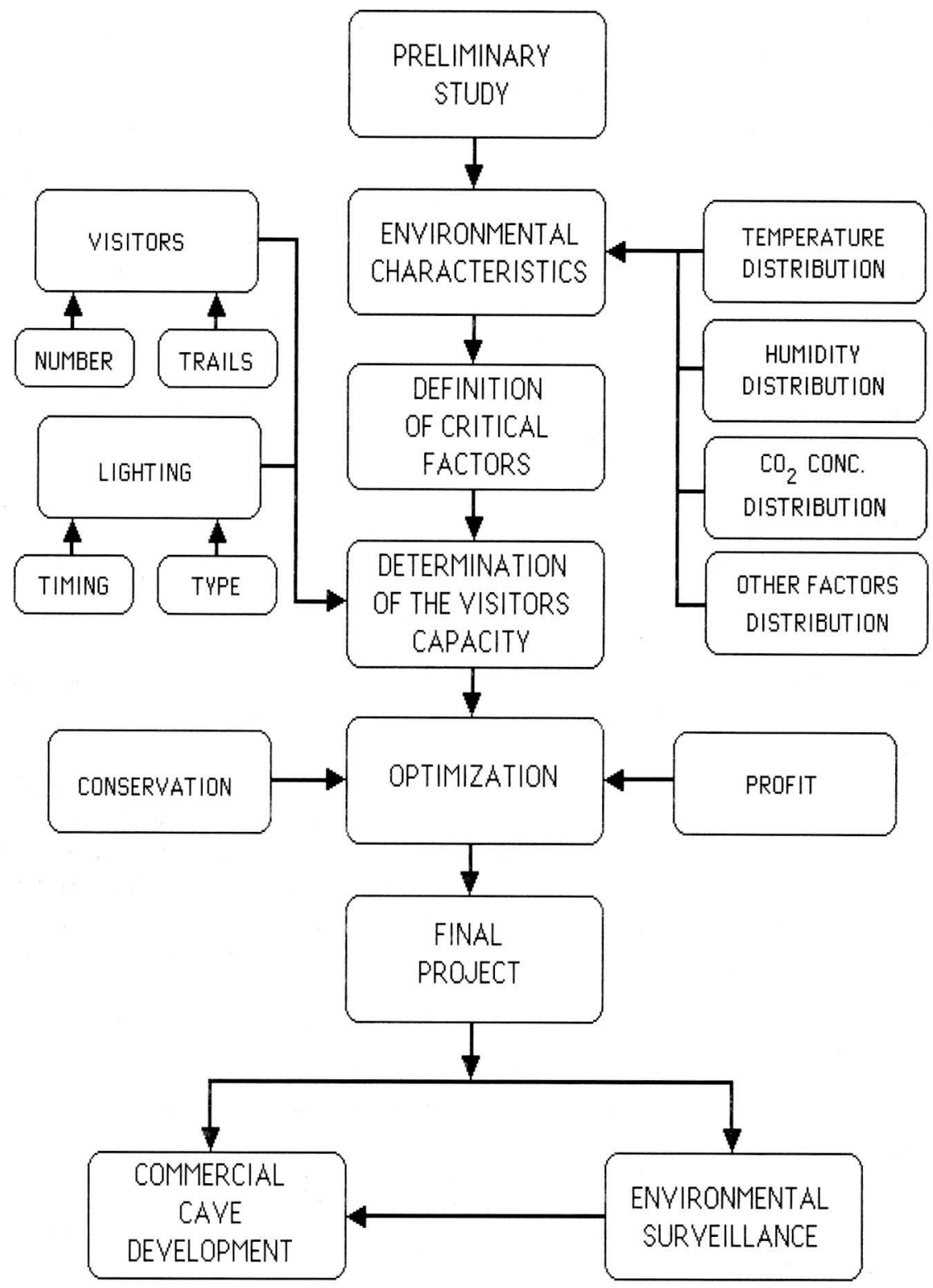

Fig. 4 - The Environmental Impact Assessment for the development of a tourist cave. 
Such results must be emphasised because too often the development of a cave into a show cave is considered a pure loss for science. To the contrary if the development is carried out according the principles of cave conservation, the final balance will be largely positive because a small fraction of the commercial profit of the show cave may provide an invaluable source for a research budget.

In addition to this advantage, there is also a direct positive effect on the protection of the cave environment, because when part of a large system is developed for tourism, a control is automatically assured also for the other parts of the cave which would have been open to everyone if the cave would have remained wild (Gurnee, 1967; Forti, 1996). These considerations introduce to another argument, the economy in connection with show caves.

\section{Show caves and economy.}

Dell'Oca has published one of the first papers dealing with this subject (1962) and it was concerned with many different aspects of the use of caves with an economical involvement. In particular it was pointed out the effect of a show cave development on the local economy and the example of Castellana Caves (Puglia, Italy) was described.

It is evident that the economy of a region around a show-cave-to-be can be radically modified by the cave development. Therefore strenuous opposition to any tourist visitation appears to be rather unfair towards the local people particularly when a suitable compromise between strict conservation and a sound development can be found. But in any case, as it was previously reported, a cave development cannot be accepted if it is not supported by appropriate preliminary research.

In Table 1 nearly 200 show caves of 28 countries from all over the world are reported with the indicative number of visitors per year. It must be stressed that such figures are not homogeneous because they have been determined according to different criteria. In particular the number of visitors per year is not constant and varies as a consequence of many factors. The number reported in the table refers to a recent year in some case or refers to an average among some years in some others.

Table 1 - Some important show caves from all over the world.

COUNTRY Show Cave Region $\quad N^{\circ}$ of visitors per year

ARGENTINA Caverna de las Brujas

AUSTRIA

AUSTRALIA
Eisriesenwelt

Rieseneishöhle

Abercrombie Caves

Jenolan Caves
Mendoza

12,000

Salzburg

150,000

Oberösterreich

120,000

New South Wales

10,000

New South Wales 


Wee Jasper Caves (Careyís)
Wellington Caves
Wombeyan Caves
Yarrangobilly Caves
Buchan Caves
Princess Margaret Rose Caves
Murrindal Caves
Cammoo Caves
Olsens Capricorn Caverns
Chillagoe Caves
Undarra Lava Tubes
Cutta Cutta Caves
Englebrecht Cave
Naracoorte Caves
Tantanoola Caves
Gunns Plains Cave
Hastings Caves
Augusta/Maragaret River Caves
Ngilgi Cave, Yallingup

$\begin{array}{ll}\text { BELGIUM } & \text { Grotte de Han } \\ \text { BERMUDA } & \text { Crystal Caves } \\ & \text { Gruta de Maquiné } \\ & \text { Gruta da Lapinha } \\ & \text { Gruta Rei do Mato } \\ & \text { Nucleo Santana (3 caves) } \\ & \text { Caverna do Diabo } \\ & \text { Grutas de Intervales } \\ & \text { Poço Encantado } \\ & \text { Gruta Botuverá } \\ & \text { Gruta Angélica } \\ & \text { Gruta dos Ecos } \\ & \text { Gruta Terra Ronca } \\ & \text { Gruta Lago Azul } \\ & \text { Gruta São Miguel } \\ & \text { Grutas da Serra da Capivara } \\ & \text { Gruta de Maroaga } \\ & \text { Gruta de Ubajara } \\ & \text { Gruta do Castelo } \\ & \text { Gruta dos Martins }\end{array}$

New South Wales

New South Wales

42,000

New South Wales

30,000

New South Wales

23,000

60,000

10,000

2,000

10,000

35,000

18,000

40,000

34,000

10,000

60,000

20,000

10,000

38,000

60,000

65,000

Namur

500,000

Bermuda

80,000

Minas Gerais

47,000

Minas Gerais

36,000

Minas Gerais

30,000

São Paulo

24,000

São Paulo

27,000

São Paulo

12,000

Bahia

$>5,000$

Paraná-Santa Catarina

7,000

Goiás

3,000

Goiás

20,000

Goiás

7,000

Mato Grosso

44,000

Mato Grosso

5,000

5,000

4,000

47,000

20,000

9,000 
Benxi Water Cave

Biyundong Cave

Boyundong Cave

Furongdong Cave

Guilin Reed Flute Cave

Huang Long Cave

Jiutiendong Cave

Kongshan Baiyun Cave

Longgong Cave

Longgong Cave

Shanjuan Cave

Shihua Cave

Snow Flower Cave

Taiji Cave

Tanglong Cave

Tianquan Cave

Wolongdong Cave

Yaolin Cave

Yuhua Cave

Yunfu Panlong Cave

Zhijing Cave

Zhiyundong Cave

CZECH REPUB. Bozkov Dolomite Cave

Konìpruské Caves

Chynovská Cave

Zbrasov Aragonite Caves

Javoricko Caves

Mladec Caves

Na Pomezi Caves

Na Spikaku Caves

Punkva Caves

Balcarka Cave

Katerinska Cave

Sloupsko-sosuvske Caves

FRANCE
Grotte d'Arcy

Aven Armand

Grotte de la Balme

Abîme de Bramabiau

Grotte de Grandes Canalettes

Grotte de Choranche

Grotte de Clamouse

Grotte la Cocalière

$\begin{array}{ll}\text { Liaoning } & 280,000 \\ \text { Guzhou } & 150,000 \\ \text { Hunan } & 300,000 \\ \text { Qongqing } & 300,000 \\ \text { Guangxi } & 920,000 \\ \text { Hunan } & 300,000 \\ \text { Hunan } & 200,000 \\ \text { Hebei } & 170,000 \\ \text { Guizhou } & 400,000 \\ \text { Jiangxi } & 300,000 \\ \text { Jiangsu } & 400,000 \\ \text { Beijing } & 380,000 \\ \text { Henan } & 250,000 \\ \text { Anhui } & 200,000 \\ \text { Hubei } & 200,000 \\ \text { Sichuan } & 350,000 \\ \text { Yunnan } & 250,000 \\ \text { Zhejiang } & 370,000 \\ \text { Fujiang } & 300,000 \\ \text { Guangdong } & 200,000 \\ \text { Guizhou } & 150,000 \\ \text { Yunnan } & 500,000 \\ & \end{array}$

East Bohemia $\quad 75,000$

Central Bohemia $\quad 125,000$

South Bohemia $\quad 40,000$

Central Moravia $\quad 50,000$

Central Moravia $\quad 60,000$

Central Moravia $\quad 20,000$

North Moravia $\quad 60,000$

North Moravia $\quad 15,000$

South Moravia $\quad 195,000$

South Moravia $\quad 40,000$

South Moravia $\quad 60,000$

South Moravia $\quad 45,000$

Yonne $\quad 180,000$

Lozère $\quad 100,000$

Isère $\quad 60,000$

Gard $\quad 40,000$

Pyrénées Orientales $\quad 40,000$

Isère $\quad 150,000$

Hérault $\quad 150,000$

Gard $\quad 100,000$ 


\begin{tabular}{|c|c|c|c|}
\hline & Grotte Prehist. Foissac & Aveyron & 18,000 \\
\hline & Grotte de Fontirou & Lot et Garonne & 40,000 \\
\hline & Grotte des Demoiselles & Hérault & 150,000 \\
\hline & Grotte du Grand Roc & Dordogne & 130,000 \\
\hline & Grottes Isturitz Oxocelhaya & B. Pyrénées & 90,000 \\
\hline & Grotte Lacave & Lot & 150,000 \\
\hline & Grotte Limousis & Aude & 26,000 \\
\hline GEORGIA & Novoafonskaya & Abkhasia & 700,000 \\
\hline & Navenakhevi & Terjol & 20,000 \\
\hline & Sataplia & Tskhaltubo & 100,000 \\
\hline GERMANY & Barbarossahöhle & Thüringen & 200,000 \\
\hline & Dechenhöhle & Sauerland & 200,000 \\
\hline & Erlebnisbergwerk Merkers & Thüringen & 70,000 \\
\hline & Feengrotten & Thüringen & 200,000 \\
\hline & Hermanns and Baumannshöhle & Harz & 260,000 \\
\hline & Kluterthöhle & Westfalen & 30,000 \\
\hline & Historisches Kupferbergwerk & Hessen & 120,000 \\
\hline & Nebelhöhle & Schwäbische Alb & 100,000 \\
\hline & Teufelshöhle & Franken & 200,000 \\
\hline & Wiehler Tropfsteinhöhle & Bergisches Land & 60,000 \\
\hline HUNGARY & Abaliget Cave & Baranya & 70,000 \\
\hline & Anna cave & Bükk Natl. Park & 20,000 \\
\hline & Baradla Cave & Aggelek & 180,000 \\
\hline & Buda Castle Cave & Budapest & 50,000 \\
\hline & Szt. István Cave & Bükk Natl. Park & 60,000 \\
\hline & Lóczy Cave & Veszprém & 10,000 \\
\hline & Miskolk-Tapolca Cave & Veszprém & 100,000 \\
\hline & Pál-Völgy Cave & Budapest & 40,000 \\
\hline & Szemlö-Hegy Cave & Budapest & 10,000 \\
\hline INDIA & Vaishno Devi & Jammu & 490,000 \\
\hline IRAN & Ghar Alisadr & Hamadan & 400,000 \\
\hline ITALY & Grotta dell' Angelo & Campania & 80,000 \\
\hline & Grotta di Castellana & Puglia & 250,000 \\
\hline & Grotta di Collepardo & Lazio & 10,000 \\
\hline & Grotte di Frasassi & Marche & 350,000 \\
\hline & Grotta Gigante & Venezia Giulia & 85,000 \\
\hline & Grotta di Is Janas & Sardegna & 10,000 \\
\hline & Grotta di Ispinigoli & Sardegna & 40,000 \\
\hline
\end{tabular}


Grotta del Nettuno

Grotta di Oliero

Grotta di Pastena

Grotta di Pertosa

Grotta di Su Mannau

Grotta San Michele

Grotta di Smeraldo

Grotta di Su Marmuri

Grotta di Toirano

Grotta del Vento

Grotta di Is Zuddas

NEPAL

Mahadev Cave

Bat Cave

NEW ZEALAND Waitomo Caves

Blackwater Rafting

Te Anau Caves

Metro, Te Hahi \& Babylon.
Sardegna

Veneto

Lazio

Campania

Sardegna

Sardegna

Campania

Sardegna

Liguria

Toscana

Sardegna

Pokhara

Pokhara

North Island

North Island

South Island

South Island

Arecibo

Perm

Krasnodar

Postojna

Matavun

Tatra Natl. Park

Low Tatras

Low Tatras Natl. Park

Low Tatras Natl. Park

Slovak Paradise Natl. Park

Silicka Plateau

Lesser Carpathiana

Silicka Plateau

Greater Tatra

Jasov

Revucka Highland

Vazec

Malaga

Malaga

Leon
180,000

30,000

40,000

60,000

20,000

3,000

100,000

10,000

200,000

60,000

50,000

$>200000$

10,000

400,000

12,000

12,000

5,000

140,000

200,000

25,000

800,000

50,000

90,000

30,000

135,000

50,000

75,000

25,000

40,000

15,000

20,000

22,000

28,000

30,000

500,000

50,000

70,000 
SOUTH AFRICA Cango Cave

Oudtshoorn

250,000

SWEDEN Lummelundagrottan

TURKMENISTAN Bakhardenskaya Cave

U.K.

UKRAINE

U.S.A

Cave of the Winds

Carlsbad Caverns

Crystals Caves

Fantastic Caverns

Howe Caverns

Inner Space Cavern

Lost Sea

Luray Caverns

Mammoth Cave

Marvel Cave

Meramec Caverns

Moaning Cave

Natural Bridge Caverns

Penn's Cave

Rio Camuy Cave Park

Ruby Falls

Sea Lion Caves
Gotland

80,000

Bakharden

40,000

Somerset

260,000

S. Wales

80,000

Devon

Derbyshire

Derbyshire

Derbyshire

Lancashire

Crimea

Crimea

Crimea

Ternopol

Ternopol

Crimea

Odessa

Kiev

Colorado

New Mexico

Bermuda

Missouri

New York

Texas

Tennessee

Virginia

Kentucky

Missouru

Missouri

California

Texas

Pennsylvania

Puerto Rico

Tennessee

Oregon
115,000

120,000

390,000

82,000

66,000

220,000

60,000

50,000

70,000

25,000

200,000

50,000

$1,800,000$

$>100,000$

$>100,000$

$>100,000$

$>100,000$

$>100,000$

$>100,000$

$>100,000$

$>100,000$

$>100,000$

$>100,000$

200,000

100,000

$>100,000$

80,000

$>100,000$

$>100,000$

$>100,000$

100,000

VENEZUELA Cueva del Guacharo

Monagas 
According to Zhang \& Jin, (1996) there are about 800 show caves in the world. If it is assumed that the caves listed in Table 1, with much more than 25 million visitors, are a reasonably representative sample of all show caves, since they are $150 / 800=$ $19 \%$ of the whole, a global number of more than 150 million visitors per year may be evaluated.

By assuming a budget per person as reported in Table 2 the total amount of money spent to visit the show caves is around 2.3 billion US\$. The number of the local people directly involved in the show cave business (management and local services) can be estimated to be several hundred per cave, i.e. some hundreds of thousands of individuals in the world.

By taking into account that there are several hundred other people working indirectly to each person directly connected with a show cave (Forti \& Cigna, 1989), a gross global figure of about 100 million people receive salaries from the show cave business, i.e. it can be roughly assumed that behind each tourist in a show cave there is about one employee directly or indirectly connected.

In addition to show caves, it must be considered also the existence of karst parks, which include a cave within their boundaries. As reported by Halliday (1981) the number of visitors of three top karst national parks in USA (Mammoth Cave, Carlsbad Caverns and Wind Cave) amounted to about 2,500,000 tourists each year. Therefore karst parks give a further increase to the number of people involved in the whole "karst" business.

Table 2 - Rough estimation of the annual direct and local budget of a show cave per each visitor (US \$).

Direct income

Other local income:

Souvenirs \& snacks

Meals

Transportation

Travel agency
5

1.5

5

2

2

TOTAL 15.5

There are many other human activities which involve a larger number of people; nevertheless the figure reported above is not negligible and gives an indication of the role that show caves play in the global economy. 


\section{Acknowledgements}

I wish to acknowledge the kind cooperation of a number of colleagues in collecting data on the show caves around he world. In particular I express here my thanks to: William S. Bagshaw, Dolores Beraldo, Pavel Bosak, Patrick Deriaz, Paolo Forti, Jeannie Gurnee, Yvonne Habermann, Ernst Holland, Alexander Klimchouk, José Ayrton Labegalini, Michael Laumanns, Renata Marinelli, Ricardo J.C. Marra, Neville Michie, Barbara Munson, Song Linhua, Franco Urbani, Excma. Diputación Provincial de León (Spain).

\section{References}

ALEY T., 1976 - Caves, cows and carrying capacity. National Cave Management Proceedings 1975, 6-10 October 1975, Speleobooks, Albuquerque: 70-71.

AMAVIS R, SMEETS J., BRANCA G., BREUER F., CIGNA A., 1974 - Developpement et application du concept de la capacité radiologique en radioprotection. Proc. Symp. Aix-en-Provence, 14-18 May 1973, IAEA, Vienna: 583-592.

BERTOLANI M. \& CIGNA A.A., 1994 - Activity of the Scientific Commission of "Grotta Grande del Vento" (Genga, Ancona, Central Italy). Int. J. Spel., 23 (1-2): 51-60.

BOURGES F., D'HULST D. \& MANGIN A., 1998 - Étude de l'Aven d'Orgnac. Rapport final, Lab. Souterrain de Moulis, Géologie Environnement Conseil, Moulis.

BROWNLIE D., 1985 - Strategic Marketing Concepts and Models. J. of Marketing Management, 1: 157-194.

BURRI E. \& CIGNA A.A., 1991 - Some considerations on the potential for revitalisation of show cave. In: Sauro U., Bondesan A. \& Meneghel M, (Eds.) - Proc. Int. Conf. on Environmental Karst Areas (Italy, 15-27 Sept.,1991 ). Quad. Dip. Geografia, Univ. Padova, 13, 1991: 299-303. Also as: Rapporto ENEA RT/AMB/92/18.

BURRI E. \& FORTI P., 1995 - The karst area fo Pietrasecca (Abruzzo, Italy): a project for its preservation and touristic development. Proc. Int. Symp. "Man on Karst", Postojna Sept. 23-25, Acta Carsologica, Ljubljana: 133-145.

BRUCKER R., 1976 - Comments on carrying capacity. National Cave Management Proceedings 1975, 6-10 October 1975, Speleobooks, Albuquerque: 72.

BUTLER R.W., 1980 - The Concept of a Tourist Area Life Cycle of Evolution. Canadian Geographer, 24: 5-12.

CASTELlANI V., 1988 - Frasassi e speleomonitoraggio. Speleologia, Soc. Spel. It., 9 (18): 33-35. 
CAUMARTIN V., 1993 - Évolution des idées en matière de corrosion et de conservation du milieu souterrain. Cent ans de spéléologie française, Féd. Fr. Spél., Spelunca Mémoire, $\mathrm{n}^{\circ}$ 17, Paris: 273-275.

CAVALLARO C. \& PIPINO A., 1991 - Geografia del Turismo. Giappichelli, Torino.

CHRISTALLER W., 1933 - Die zentralen Orte in Suddeutschland. Wissenschafliche Buchgesellschaft, Jena.

CHRISTALLER W., 1964 - Some considerations of tourism location in Europe. Papers of the Regional Science Association, 12: 95-105.

CIGNA A.A., 1989 - La capacità ricettiva delle grotte turistiche quale parametro per la salvaguardia dell'ambiente sotterraneo - Il caso delle Grotte di Castellana. Atti XV Congr. Naz. Speleol., Gruppo Puglia Grotte - Amm. Comunale Castellana Grotte: 999/1012.

CIGNA A.A., CUCCHI F. \& FORTI P., 2000 - Engineering problems in developing and managing show caves. J. Nepal Geological Soc., 22: 85-94

CIGNA A.A. \& FORTI P., 1989 - The environmental impact assessment of a tourist cave. Cave Tourism . Proc. Int. Symp. 17Oth Anniv. Postojnska Jama, Postojna, Nov. 10-12, 1988. Centre Scient. Res. SAZU \& Postojnska Jama Tourist and Hotel Organiz.: 29-38.

CIGNA A.A. \& FORTI P., 1990 - La V.I.A. delle grotte turistiche. The E.I.A. of a tourist cave. VIA, l' Arca Edizioni, Milano, 4 (16): 42-53.

CSER F., GADOROS M., 1988 - The role of aerosols in cave deposition. Proc. Int. Symp. on Phys. Chem. and Hydr. Research of Karst, Kosice, 10-15 May 1988, Slovenska Speleologicka Spolocnosf, Liptovsky Mikulas: 25-34.

COOPER C.P., 1989 - Tourist Produced Life Cycle. In: Witt S. \& Moutinho L. (Eds.) Tourism Marketing and Management, Prentice Hall, London: 557-582.

DELL'OCA S., 1962 - Note di speleologia economica. Atti VI Congr. Spel. Lombardo, 10 Apr. 1960, Rass. Speleologica Italiana, XIV (1): 76-109.

FORSSELL S., 1977 - The concept of carrying capacity and how it relates to caves. National Cave Management Proceedings 1976, 26-29 October 1976, Speleobooks, Albuquerque: 1-5.

FORTI P., 1980 - Formazione di aragonite nella Grotta di Castellana: un esempio della modificazione indotta dalla turisticizzazione. Grotte d'Italia, s.4, 8:1-10.

FORTI P., 1996 - Turisticizzazione e tutela dell'ambiente ipogeo: due aspetti non contrastanti. In: Cigna A.A. (Ed.) - BOSSEA MCMXCV. Proc. "Show Caves and Environmental Monitoring" Symp. Int., Frabosa Soprana (Cuneo) 2427/III/1995: 49-56. 
FORTI P., CIGNA A.A., 1983 - Relazione della Commissione tecnico scientifica per lo studio di alcuni fenomeni di infiltrazione nelle Grotte di Castellana. Unpublished report for the Amministrazione Provinciale di Bari.

FORTI P. \& CIGNA A.A., 1989 - Cave tourism in Italy: an overview. Cave Tourism . Proc. Int. Symp. 17Oth Anniv. Postojnska Jama, Postojna, Nov. 10-12, 1988. Centre Scient. Res. SAZU \& Postojnska Jama Tourist and Hotel Organiz.: 46-53.

GURNEE J. (Ed.), 1967 - Conservation through Commercialisation. Bull. Natl. Spel. Soc., 29 (2): 27-71.

GURNEE J., 2001 - Personal communication to A.A. Cigna.

GURNEE R., GURNEE J., 1981 - The study report on the development of Harrison Cave, Barbados, West Indies. Atti Conv. Int. Grotte Turistiche, Borgio Verezzi 20-21 Marzo 1981; Grotte d'Italia, s.4, 10:101-107.

GURNEE R., 1990 - Personal communication to A.A. Cigna.

HALLIDAY W.R., 1981 - Karstic national parks: international economic and cultural significance. Proc. Int. Symp. Utilization of Karst Areas, Trieste March 29-30, 1980. Ist. Geol. e Paleont. - Commissione Grotte Boegan, CAI Trieste: 135-144.

HAMMITT W. \& COLE D., 1987 - Wildland Recreation: Ecology and Management. Wiley Interscience, John Wiley \& Sons, New York.

HEATON T., 1986 - Caves. A Tremendous Range in Energy Environments on Earth. National Speleological Society News, August: 301-304.

HUPPERT G., BURRI E., FORTI P. \& CIGNA A., 1993 - Effect of Tourism Development on Caves and Karst. In: P. W. Williams (Ed.) - Karst Terrains, Environmental Changes and Human Impact. Catena Supplement 25: 251-268.

IMPRESCIA U., 1983 - Considerazioni teoriche sulla radiazione emessa da vari tipi di lampade in relazione alla formazione alla crescita di alghe e muschi sulle pareti illuminate di grotte turistiche. Grotte d'Italia, s.4, 11:93/-101.

INNOCENTI P., 2000 - Geografia del Turismo. Carocci, Roma.

ISARD W., 1960 - Methods of Regional Science. An Introduction to Regional Science. The Technology Press of MIT, New York.

JABLONSKY P., 1990 - Lint is not limited to belly buttons alone. National Speleological Society News, 48 (5): 117-119.

LOSCH A., 1954 - The Economics of Location. Yale Univ. Press, New Haven.

MARRA R.J.C., 2001 - Espeleo Turismo. Planejamento e manejo de cavernas. Esitora WD Ambiental, Brasilia. 
MERENNE-SCHOUMAKER B., 1975 - Aspects de l'influence des touristes sur les microclimats de la grotte de Remouchamps. Ann. Spéléol., 30(2): 273-285.

MICHIE N., 1996 - Investigation of visitors impacts at Jenolan Caves (N.S.W., Australia). In: Cigna A.A. (Ed.) - BOSSEA MCMXCV. Proc. "Show Caves and Environmental Monitoring" Symp. Int., Frabosa Soprana (Cuneo) 2427/III/1995:235-239.

MICHIE N., 1997 - The threat to caves of the human dust sources. Proc. $12^{\circ}$ Int. Congr. Spel. LaChaux-de-Fonds, Switzerland, Symposium 5: Applied Speleology, 5: 43-46.

MIDDAUGH G., 1977 - Practical experiences with carrying capacity. National Cave Management Proceedings 1976, 26-29 October 1976, Speleobooks, Albuquerque: 6-8.

MIOSSEC J. M., 1976 - Elements pour une theorie de l'espace touristique. Les Cahiers du Tourisme, C36. Centre des Etudes Touristiques, Aix-en-Provence.

MIOSSEC J. M., 1977 - Un modèle de l'espace touristique. L'Espace Geografique, 8(1): 4148.

MONGELLI F., 1961 - Rilievo della temperatura dell'aria nelle Grotte di Castellana. Boll. Geofis. Teor. Appl., 3 (11): 197-208.

VAN CLEAVE P., 1976 - Some thoughts on the carrying capacities of developed caves. National Cave Management Proceedings 1975, 6-10 October 1975, Speleobooks, Albuquerque: 73-74.

VILLAR E., BONET A., DIAZ-CANEJA B., FERNANDEZ P.L., GUTIERREZ I, QUINDOS L.S., SOLANA J.R., SOTO J., 1984 - Ambient temperature variations in the hall of paintings of Altamira cave due to the presence of visitors. Cave Science, Trans. British Cave Research Association, 11(2), July: 99-104.

VILLAR E., BONET A., DIAZ-CANEJA B., FERNANDEZ P.L., GUTIERREZ I, QUINDOS L.S., SOLANA J.R., SOTO J., 1985 - Natural evolution of percolation water in Altamira cave. Cave Science, Trans. British Cave Research Association, 12(1), March: 21-24.

VILLAR E., FERNANDEZ P.L., GUTIERREZ I, QUINDOS L.S., SOTO J., 1986 - Influence of visitors on carbon dioxide concentrationns in Altamira Cave. Cave Science, Trans. British Cave Research Association, 13(1), April: 21-23.

ZHANG S., JIN Y., 1996 - Tourism resources on jarst \& caves in China. Actas II Congr. ISCA 29 Oc.-1 Nov. 1994, Malaga, 111-119.

Received 12 June 2001

Accepted 15 September 2001 